\title{
INTRODUCTION: A SCHOLARLY SNAPSHOT
}

\section{Graeme W Austin*}

Graeme W Austin, Associate Dean (Research) and Chair of Private Law, Introduces this 60th Anniversary edition of the Victoria University of Wellington Law Review. He provides a snapshot of a day in the life of the Victoria University of Wellington Law Faculty, focusing on the research activities of his colleagues, and reflects on what this might mean for the future of legal scholarship at Victoria.

"What is legal scholarship?" For almost every legal academic, this will be a familiar question. It was recently asked of me by a senior solicitor during a Wellington social event. This question, which often follows the customary icebreaking pleasantries, was prompted by my characterisation of law faculty positions as requiring around 40 per cent of time to be devoted to teaching, 40 per cent to legal scholarship, and 20 per cent to institutional and public service. Only the reference to "legal scholarship" provoked further inquiry.

In many respects, this 60th Anniversary edition of the Victoria University of Wellington Law Review provides a compelling answer. The 13 articles and essays gathered here by some of the fulltime professional legal scholars who comprise Victoria University of Wellington's Faculty of Law manifest the very best qualities of legal research and writing. It is a fitting tribute to the scholarly expertise of those who currently hold faculty positions in this Law School that the Editorial Committee of the VUWLR has chosen to mark this anniversary by showcasing their work. The papers are expert and relevant, and reflect the diversity of issues to which legal research contributes.

Even so, this edition provides only a small snapshot of the scholarly endeavours of the Victoria University of Wellington Law Faculty since the inauguration of this publication. As the Dean of the

* Associate Dean (Research) and Chair of Private Law, Victoria University of Wellington. Thanks to the Editorial Committee of the VUWLR for the invitation to write the Introduction to the 60th Anniversary edition, to Nessa Lynch for her expert and patient editorial work, and to my inspiring Law Faculty colleagues who contributed to this article. 
Law Faculty, Professor Tony Smith has eloquently described in his Preface, ${ }^{1}$ the VUWLR inherits a venerable tradition dating back to its 1953 founding by Professor Robert McGechan.

Today's faculty are, as is the case with any fine institution, only temporary stewards. Our relationship with the VUWLR - indeed, with the Law Faculty itself - is informed by the deepest respect for those who came before us, and is animated more by a sense of responsibility than proprietorship. That which characterises fine legal scholarship in the second decade of the 21st century is an accretion of traditions and innovations developed by many earlier generations of scholars. Legal scholarship is also informed by an acute awareness of and dialogue with the work of legal scholars and jurists in other jurisdictions. As Professor Smith explains, the VUWLR was itself an innovation that drew from the United States university law review tradition.

If these traditions represent the past, and this 60th Anniversary edition the present, what of the future? Any description of the future of legal scholarship is necessarily speculative. We can only guess at how our scholarship and teaching will respond to the profound changes that are currently occurring in the discipline of Law and in the marketplace for legal services, ${ }^{2}$ including the increasing internationalism of legal practice, and, perhaps most significantly, the possible decline of the "Cravathesque" law firm. More immediate effects may come from the "Performance-Based Research Funding" (PBRF) scheme ${ }^{3}$ under which all New Zealand academics must now labour, notwithstanding questions as to its "fit" with distinct academic and professional disciplines, including Law. As its economic incentives continue to be internalized, the PBRF scheme will inevitably come to influence the future direction of legal scholarship produced within New Zealand universities. The Victoria University of Wellington Law Faculty is justly proud of its success in the latest PBRF round, but we also hope that the PBRF scheme neither affects detrimentally the vibrancy of the dialogue that currently exists between New Zealand academics, the profession, and the courts nor threatens the viability of New Zealand-based law reviews such as this one.

Legal scholarship is, amongst other things, an iterative process. In the common law world scholarship tends to reflect the common law method. Seldom welcome or useful are pretentions to "shift paradigms". Our work is stronger for the incrementalism that typically characterises it. Legal

$1 \quad$ At 415 .

2 See for example Australian Financial Review "Major firms tested as legal world changes" (28 June 2013) <www.afr.com>.

3 See Tertiary Education Commission Performance-Based Research Fund Guidelines 2006 (Wellington, July 2005). For commentary on the PBRF scheme see Michael Taggart "Some Impacts of PBRF on Legal Education" in Claudia Geiringer and Dean F Knight (eds) Seeing the Whole World: Essays in Honour of Sir Kenneth Keith (Victoria University Press in association with NZ Centre of Public Law, Wellington, 2008) 250; Claudia Geiringer "Book Review: Human Rights and Intellectual Property: Mapping the Global Interface by Laurence R Helfer and Graeme W Austin" (2012) 34 Hum Rts Q 652; Petra Butler and Roderick Mulgan "Can Academic Freedom Survive Performance Based Research Funding?" in this edition. 
scholarship is a subtle choreography between creativity and discipline. Research traditions of course adapt and evolve, but it is to be hoped that the catalysts of change derive principally from the discipline of Law itself, and its relationship with the communities we serve and the other academic disciplines to which we respond, rather than financial exigencies. If the past and present augur the future, members of the Victoria University of Wellington Law Faculty will continue to make exceptional contributions to the development of legal science, participate in law reform, reflect on the traditions and cultural contexts that inform the present, and lead and take part in dialogues both domestic and international - on law's role in shaping the commercial marketplace, contributing to the functioning of government and civil society, and enhancing the dignity of individuals and peoples.

To prepare for writing this Introduction to the 60th Anniversary edition, I asked my colleagues to describe their research activities on 17 October 2013. I chose this day in part because it was still within the teaching period. On 17 October, 21 law classes were taught at the Law School, including large compulsory or quasi-compulsory classes, such as Torts, Criminal Law, Property, Business Associations and Evidence, as well as a number of more specialist offerings. In addition, 43 tutorials ran that day, mostly taught by student tutors who work closely under the supervision of the permanent faculty (who are also responsible for crafting the tutorial problems themselves, integrating the tutorial programme with the large classroom instruction, and drafting detailed teaching notes). A significant amount of research activity was also being undertaken that day, a reality of law school life that underscores the deep links between scholarship and teaching. To have interesting things to say in the classroom demands the same kind of intellectual rigour, engagement and expertise that characterises the very best scholarship. But what exactly was happening in the Law School buildings on 17 October 2013? Here is another snapshot.

That morning, Tony Angelo was meeting with research assistants assisting him with the second edition of the Seychelles Digest, the only scholarly work that focuses on the Seychelles. ${ }^{4} \mathrm{He}$ also worked on the new edition of the Mauritius Private International Law. ${ }^{5}$ Later in the day, he worked on a chapter about Mauritius for a new book on endangered legal systems, scheduled for publication in early $2014 .^{6}$

Tony Angelo's work on 17 October was also directed toward another important aspect of Victoria University of Wellington's contribution to legal research: our growing cohort of doctoral and research-based masters students. Tony directs our PhD programme. At any one time, the Law

4 For earlier editions, see MJ Gerard Lalouette The Seychelles Digest (M J G Lalouette, Seychelles, 1982); Tony Angelo Seychelles Digest (Law Publications, Wellington, 2011).

5 Tony Angelo and Victor Glover International Encyclopaedia for Private International Law: Mauritius (The Netherlands, Wolters Kluwer, 2010).

6 Tony Angelo "Mauritius" in Sue Farran (ed) Endangered Legal Systems (Ashgate, 2014) (forthcoming). 
Faculty is home to 16-20 PhD candidates, from New Zealand and across the globe, who are attracted to Victoria for the expert supervision provided by our faculty on a diverse range of topics, including "copyright and the rights of the visually impaired", "conflict of laws and private ordering", "indigenous land tenure in Taiwan", and "alternatives to prison for adult sex offenders".

Meanwhile, Gordon Anderson was working on a draft chapter of his new book Employment Law in New Zealand. ${ }^{7}$ This text will provide a comprehensive analysis of employment law while also serving as a teaching tool. To that end, Gordon initiated a meeting with his Employment Law class representative (a student who is elected by his or her peers to serve in this role) to solicit students' view as to how the course might be adapted in the light of this new text. Gordon is also director of our growing LLM programme, which includes a number of candidates who are completing their degrees through independent research programmes or by a combination of independent research and taught courses.

Bill Atkin spent part of the day examining an LLM thesis from Canterbury University. He was also preparing for a meeting of the Human Ethics Committee, which he chairs for the Pipitea Campus. Ethics approval is an integral part of much empirically-based research, including work of the kind described below by Yvette Tinsley and Nicole Moreham on media intrusion and the role of privacy law. Bill was also continuing with research on changes to the Domestic Violence Act 1995 for the LexisNexis Family Law Service, a leading New Zealand practitioner treatise on family law. Bill has been a member of the authorship team on this publication since its inception in 1981.

Mark Bennett was preparing for a presentation in the Law Faculty's Academic Enrichment Programme, a series of seminars in which faculty present works-in-progress and receive collegial feedback from other VUW legal scholars and our PhD students. The Academic Enrichment Programme is one of the vehicles for enhancing the quality of the research that is produced by the Faculty of Law. The seminar series also contributes more generally to the Faculty's intellectual life. Mark was also preparing for a seminar presentation he had been invited to give at the Julius Stone Institute at the University of Sydney Law School in early November. Mark's talks were on "Fuller's challenge and the self-understanding of legal positivism," a topic that is also part of a book project Mark is developing from his doctorate in law, awarded by the University of Toronto in 2013.

At the same time, Richard Boast was in his office proofreading his latest book, The Native Land Court 1882-1887: A Historical Study, Cases and Commentary. ${ }^{8}$ Writing this book involved transcribing and editing over 150 early judgments of the Native Land Court, many of which only exist in manuscript. Later in the day, he could be found at the National Archives checking and transcribing early decisions of the Native Land Court for the second volume, which covers the

7 Gordon Anderson and John Hughes Employment Law in New Zealand (LexisNexis, 2014) (forthcoming).

8 Richard Boast The Native Land Court 1862-1887: A Historical Study, Cases and Commentary (Brookers, Wellington, 2013). 
period from 1887-1909. Other parts of the day were spent setting up meetings with the research team associated with his Marsden Research Grant. Richard was awarded the Marsden Grant in 2012 for a three-year period to carry out research on comparative tenurial change on the Pacific rim in the 19th century which will involve comparative studies of a number of countries, including Taiwan, Mexico, Costa Rica, and Hawaii, as well as New Zealand.

Meanwhile, Alberto Costi was busy that morning working on his current research project on the authority to detain in international law. He also finalised the travel details of a conference trip to Canada to attend the annual meeting of the Canadian Council on International Law in November 2013 where he will be giving a paper on the binding nature of international financial regulations. Later that day, he prepared guidelines for the student who will hold a Summer Scholarship to assist him with a project that addresses the implications of climate change on human rights and state sovereignty. The Summer Scholarship programme enables students to work closely with faculty members on research projects. The scheme assists with the research produced by the faculty, while providing students the opportunity to develop their research, analytical and writing skills under close supervision of a permanent faculty member.

In his capacity as co-ordinator of our flagship LLB(Hons) programme, Joel Colón-Ríos spent the morning reading Honours students' research essays. He also replied to an email sent from the Constitutional Court of Colombia, in which he was informed that a book containing a public lecture he gave in Bogotá on the occasion of the 20th Anniversary of the Colombian Constitution, had just been published. Later this year, Joel's second book, La Constitución de la Democracía, will also be published in Colombia. ${ }^{9}$ The book examines the implications of the theory of constituent power for contemporary constitutional states, a topic he has been researching for the past few years. As part of this research, he just completed a paper that looks at the English origins of the concept of constituent power, and which will be published in The Law Quarterly Review in 2014.

Claudia Geiringer was finalising the edits on the latest edition of the New Zealand Journal of Public and International Law, another of the scholarly law journals published by the Victoria University Law Faculty. Claudia currently serves as its editor, together with Petra Butler. The particular issue focuses on the New Zealand Bill of Rights Act 1990, the same topic for which Claudia has recently been rewarded a major Marsden Fund Research Grant to study the Act's record of performance during its first quarter century. Later in the day she could be found in her office writing references for former students to undertake LLM study in the United States and working on a blind peer review report on an article for a leading Australian law school. Blind refereeing of articles is a quality control mechanism used by leading scholarly journals. They seek out leading academics to comment on the quality of the articles submitted to them. Victoria Law School faculty

9 Joel Colón-Ríos La Constitución de la Democracía (Columbia, 2013) (forthcoming). 
are frequently called on to participate in this process - testimony to their standing in their specialist fields.

Catherine Iorns was busy in her office preparing for a trip to Copenhagen, Denmark, and Lund, Sweden, where she had been invited to speak on her work on the intersection of environment and human rights, as well as preparing for her participation in a workshop on Sustainable Development ${ }^{10}$ and a UN Consultation on Human Rights and the Environment. ${ }^{11}$

Carwyn Jones spent part of the morning shortlisting student editors for the Māori Law Review, which was relaunched at the Law School in 2012. Carwyn who edits the Review, sees student involvement with these kind of scholarly endeavours as critically important. Carwyn commented: "For any area of law to be strong and vibrant it is really important that new voices are engaged and fresh perspectives are brought to bear on the central issues in the field". He was also doing more planning work for his "Legal Traditions of Wairoa" project. This is a pilot project which has involved Carwyn and his research assistants working with a small group of kaumatua (elders) from the Wairoa area to test and develop ways of identifying legal rules and principles from within traditional Māori stories.

Nessa Lynch could be found in the central university Library, continuing her research on the Vulnerable Children Bill. ${ }^{12}$ One of a number of Victoria Law Faculty to adopt interdisciplinary perspectives on their work, Nessa also met with a colleague from the Institute of Criminology with whom she is collaborating on plans for a conference in 2014. Later in the day, Nessa met with her student research assistant who will assist her with writing an article on the legal framework underpinning the collection and retention of DNA in New Zealand. Nessa's interest in the use of DNA in the legal process will also be reflected in Law Foundation funded research she is conducting on the collection of DNA in the pre-trial process.

Campbell McLachlan presented a paper "The interaction of international law and municipal law: the case for an allocative approach in foreign relations cases" (a chapter from his forthcoming book Foreign Relations Law - to be published in 2014 by Cambridge University Press) for discussion at a lunchtime Faculty enrichment seminar. Campbell has been greatly assisted in this project by the award of the International Research Fellowship from the New Zealand Law Foundation.

10 Andrew Boyle "Human Rights and the Environment" (paper presented at the Asia-Europe Foundation's 13th Informal ASEM Seminar on Human Rights, Copenhagen, October 2013).

11 "Human Rights and the Environment: Consultation on the Relationship between Environmental Protection and Human Rights Obligations" (convened by the UN Independent Expert on Human Rights and the Environment with the Office of the High Commissioner for Human Rights, October 2013).

12 Vulnerable Children Bill 2013 (150-1). 
Having just completed the first draft of a major article on the law of implied terms in contract and given it to his student research assistant for editing and cite checking, David McLauchlan was busy preparing two separate seminar papers on aspects of the law of contract interpretation for presentation to the Perth and Brisbane legal professions in the new year.

After finalising written feedback for her students on the oral assessment component of her Evidence course, Elisabeth McDonald could be found in her office reading cases in preparation for writing the third edition of The Evidence Act 2006: Act and Analysis, ${ }^{13}$ whose authorship team includes Yvette Tinsley. That same day, Elisabeth received news that the Court of Appeal ${ }^{14}$ had favourably mentioned her co-authored text Principles of the Law of Criminal Evidence. ${ }^{15}$ In the afternoon, she was on the telephone discussing the timing of her appearance to speak to the Social Services Select Committee about her submission to the "Inquiry into the Funding of Specialist Sexual Violence Social Services".

On a day when he was teaching in two different courses - Maritime Law and Property Law Bevan Marten was also corresponding with colleagues in Utrecht and Oslo regarding his recent monograph Port State Jurisdiction and the Regulation of International Merchant Shipping. ${ }^{16}$

Nicole Moreham was continuing with revisions of an article on non-informational breaches of privacy. The legal regulation of privacy is the focus of Nicole's work for which she has been awarded a major Rutherford research grant. The working title of the article is "Beyond Information: The Protection of Physical Privacy in English Law". Later in the day Nicole met with Yvette Tinsley to discuss the appointment of a student research assistant for their project on privacy and media intrusion. For this project, Yvette and Nicole have interviewed 18 relatives and friends of the victims of the Pike River mine disaster about the impact media attention has had on their lives. They will shortly be writing up their results in a series of articles.

Grant Morris was engaged in research on New Zealand Court of Appeal judgments from 1865 to 1875 which featured James Prendergast as Attorney-General representing the Crown. This was further background work to Grant's biography of Justice Prendergast, New Zealand's third Chief Justice, which will be published by Victoria University Press in 2014. Grant was also busy with correspondence promoting the most recent edition of the VUWLR, for which he was special

13 Scott Optican, Richard Mahoney, Elisabeth McDonald and Yvette Tinsley The Evidence Act 2006: Act and Analysis (2nd ed, Thomson Reuters, Wellington, 2010).

14 Smith $v R$ [2013] NZCA 362 at [40].

15 Elisabeth McDonald Principles of Evidence in Criminal Cases (Brookers, Wellington, 2012).

16 Bevan Marten Port State Jurisdiction and the Regulation of International Merchant Shipping (Springer, Heidelberg, 2013). 
editor. ${ }^{17}$ This edition is entitled "Recovering the Common Good" and is based on a conference which Grant helped organise at Parliament in 2012.

Joanna Mossop was in her office checking the contract she has just received from Oxford University Press for her new book The Law of the Extended Continental Shelf. With research supported by the New Zealand Law Foundation and by the Law Faculty research fund, Joanna's book is a study of of the legal regime that applies to activities taking place on the continental shelf beyond 200 nautical miles.

During the morning, John Prebble attended a meeting with the publishers to commission several authors for books in the Thomson Reuters Tax Library, which he edits with Judge Paul Barber. He then met with one of our LLB(Hons) students, who had just been selected to hold a Summer Scholarship to abstract Professor ATH Smith's academic papers and to post them on the Social Science Research Network - a major on-line repository of legal research on which the Victoria Law School has an increasingly important profile. John also settled the appointments two other Summer Scholars, who will work on one of John's books in the Tax Library. He then turned to a report on a doctoral thesis that he is examining and to checking a draft of the second edition of Prebble and Griffiths The Taxation of Property Transactions due for publication by Lexis Nexis in 2014.

Caroline Sawyer spent the day working on a variety of research projects, including her article in this edition, and preparing the ground to work on a case note on the United Kingdom Supreme Court case of Al-Jedda ${ }^{18}$ and to update her sections of the Oxford University Press textbook on immigration and asylum law. ${ }^{19}$ She was also working on a jointly-authored paper on cultural rights in New Zealand.

Like many of Victoria's legal academics, Māmari Stephen's research and teaching are deeply integrated. On 17 October, Māmari was working on research toward her forthcoming book on social security law. The same research will be useful for her summer school law course on this topic. Later that day, she met with other Māori and Pasifika academic staff about improving the Māori and Pacific Island tutorial support programme. That day she also completed a submission on the Credit Contracts and Financial Services Law Reform Bill. ${ }^{20}$

During the morning, Yvette Tinsley reviewed coding manual edits for the New Zealand Crime and Safety Survey for which she has been appointed as a specialist consultant. At lunchtime, she gave a seminar in the Institute of Criminology titled, "What's law got to do with it" which drew

17 (2013) 44(2) VUWLR.

18 Secretary of State for the Home Department v Al-Jedda [2013] UKSC 62.

19 Gina Clayton Textbook on Immigration and Asylum Law (5th ed, Oxford University Press, Oxford, 2012) (contributor).

$202013(104-1)$. 
from her ongoing empirical research project on juries. This project, whose co-researchers are based in New Zealand and Australia, has received funding both from Australian funders and from the New Zealand Law Foundation. Later in the day, she arranged a meeting with her Australian counterparts on the project. She also met with Nicole Moreham to discuss their Pike River project. And, like Elisabeth McDonald, Yvette was engaged in preliminary work preparing for the third edition of The Evidence Act 2006: Act and Analysis. ${ }^{21}$

Not all of the important research work being conducted on 17 October was occurring in the Law School Building. On the other side of the world, Petra Butler was discussing the advantages of the United Nations Convention on the International Sales of Goods (1980) with colleagues at the Universidad de Navarra, where Petra has been visiting during her research leave. During her time away, Petra has delivered guest lectures at Universidad Carlos III de Madrid and Baker \& McKenzie (Madrid) on international contract law and the importance of human rights in the business context. In addition, she presented seminar papers at leading institutions, including the European University Institute in Florence. Meanwhile, Susy Frankel, a recent recipient of a Fulbright Fellowship, is currently based at New York University Law School, where she is conducting research for her new text, Supporting Intellectual Property's Innovation and Creativity Goals through Dynamic Interpretation of International Agreements: A Hermeneutic of International Intellectual Property. Paul Scott, a recipient of a Hauser Fellowship, is also at NYU Law School, where he was continuing his research on the influence of US antitrust law on New Zealand competition law, and was preparing a paper for a major NYU conference focusing on United States $v$ Philadelphia National Bank. ${ }^{22}$ Dean Knight, meanwhile, was en route to London where he is a PhD candidate at the London School of Economics and Political Science. His thesis, Variable Intensity in Anglo-Commonwealth Administrative Law, examines the different ways the courts calibrate the depth of their supervisory lens and builds on his other work exploring the legal method in judicial review cases.

So, the next time I am asked, "What is legal scholarship?", I might respond simply, "It's what legal scholars do". This snapshot of what was happening in the Law Faculty on 17 October 2013 should be answer enough. As Associate Dean (Research) for the Law Faculty I have the privilege of working with and for a diverse group of dedicated, expert, and creative legal academics. The kinds of scholarly endeavours described above happen here day in, day out. Both humbling and inspiring, the work of my Law Faculty colleagues, including that showcased here, honours the traditions that made the Victoria Law Faculty what it is today and promises a future that is very bright indeed.

21 Above n 13

22374 US 321 (1963). 
